\section{BSCL Use Plan: Solving Biomass Recalcitrance}

M. Himmel, T. Vinzant, S. Bower, and J. Jechura

\section{Technical Report} NREL/TP-510-37902

August 2005 


\section{BSCL Use Plan: Solving Biomass Recalcitrance}

\author{
M. Himmel, T. Vinzant, S. Bower, and
} J. Jechura

Prepared under Task No. BB052340
Technical Report NREL/TP-510-37902

\section{August 2005}

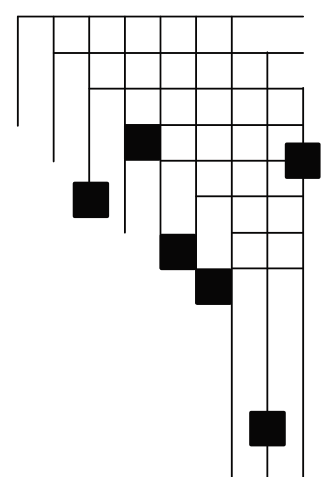




\section{NOTICE}

This report was prepared as an account of work sponsored by an agency of the United States government. Neither the United States government nor any agency thereof, nor any of their employees, makes any warranty, express or implied, or assumes any legal liability or responsibility for the accuracy, completeness, or usefulness of any information, apparatus, product, or process disclosed, or represents that its use would not infringe privately owned rights. Reference herein to any specific commercial product, process, or service by trade name, trademark, manufacturer, or otherwise does not necessarily constitute or imply its endorsement, recommendation, or favoring by the United States government or any agency thereof. The views and opinions of authors expressed herein do not necessarily state or reflect those of the United States government or any agency thereof.

Available electronically at http://www.osti.gov/bridge

Available for a processing fee to U.S. Department of Energy and its contractors, in paper, from:

U.S. Department of Energy

Office of Scientific and Technical Information

P.O. Box 62

Oak Ridge, TN 37831-0062

phone: 865.576 .8401

fax: 865.576 .5728

email: mailto:reports@adonis.osti.gov

Available for sale to the public, in paper, from:

U.S. Department of Commerce

National Technical Information Service

5285 Port Royal Road

Springfield, VA 22161

phone: 800.553.6847

fax: 703.605.6900

email: orders@ntis.fedworld.gov

online ordering: http://www.ntis.gov/ordering.htm 


\section{Table of Contents}

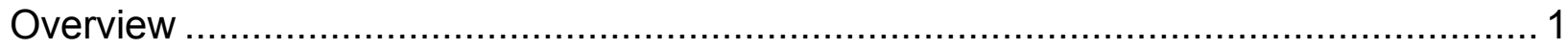

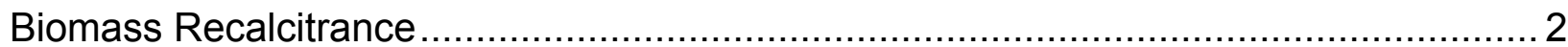

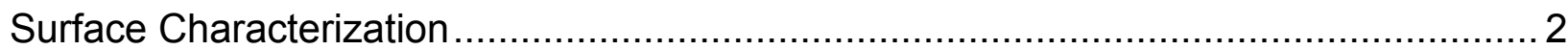

The Biomass Surface Characterization Laboratory ............................................ 2

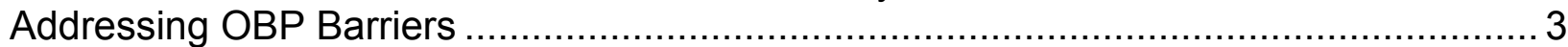

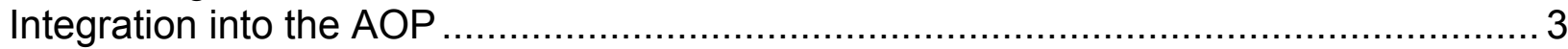

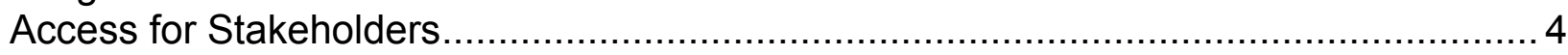

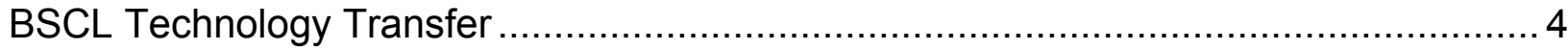

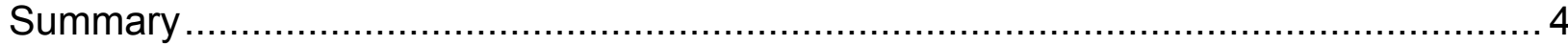

Appendix A: Tools of Surface Characterization .................................................... 7

Appendix B: Specific Strategies to Use BSCL Tools to Overcome Biomass

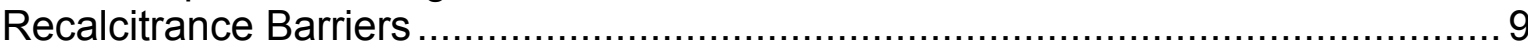

Appendix C: BSCL Use Plan .......................................................................... 13 


\section{BSCL USE PLAN: Solving Biomass Recalcitrance}

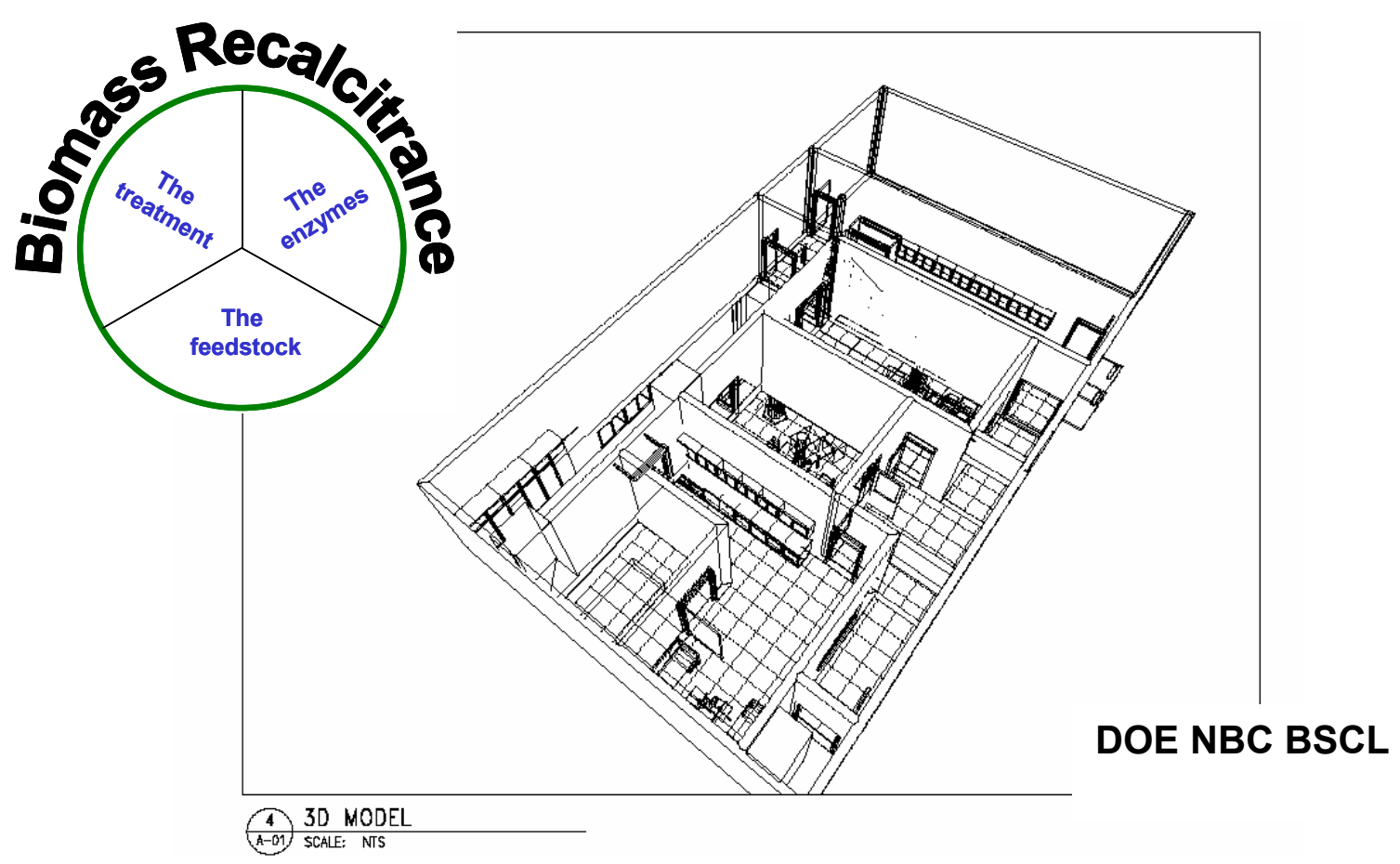

\section{Overview}

Saccharification of lignocellulosic biomass has long been recognized as a potential low-cost source of mixed sugars for fermentation to fuel ethanol or chemicals. Several technologies have been developed over the years that allow this conversion process to occur, yet the significant challenge remaining is to make the process cost competitive. For example, although total acid hydrolysis of lignocellulosic biomass has until recently been considered to be the most cost-effective process, it is still not competitive with petroleum and represents relatively mature technology with only modest opportunities for further cost reductions.

Recent cellulase cost reductions achieved by the Office of the Biomass Program (OBP) supported industrial subcontracts have, for the first time, provided a real opportunity for enzymatic saccharification of lignocellulose. Although a twenty-fold reduction in enzyme cost has been achieved to date, researchers now believe that substantial further cost reductions are available for enzymatic processes. For example, enzymatic saccharification still requires a thermochemical "pretreatment" that increases the digestibility of the lignocellulosic feedstock. Technoeconomic analyses for a lignocellulose-to-ethanol process indicate major cost factors including: (1) feedstock cost, (2) enzyme cost, (3) pretreatment cost, and (4) fermentation cost. These are not independent variables. We know that more effective pretreatment can reduce enzyme cost and that more effective enzymes can improve sugar yields, thus reducing effective feedstock cost. Better fermentation organisms could utilize a wider range of the available sugars and thus also impact effective feedstock cost.

Feedstock composition impacts both the total available sugar and the types of sugars to be fermented. We now also understand that compositionally similar feedstocks can differ in their reaction to pretreatment and their resulting enzymatic digestibility; strongly suggesting that it is important to understand the unknown structural factors. Although twenty years of empirical studies have identified leading 
pretreatment options and a preferred cellulase broth, few studies have examined the structural bases of feedstock variability, pretreatment efficacy, and enzymatic saccharification.

\section{Biomass Recalcitrance}

Lignocellulosic biomass is often described as "recalcitrant". This term is used in several contexts that may, or may not, reflect the same underlying structural elements. The observation that different corn stover lots with essentially identical chemical compositions are pretreated and hydrolyzed differently has been described in terms of recalcitrance. The term recalcitrance is also used to highlight the substantial difference in severity required for the dilute acid hydrolysis of lignocellulose and starch and to explain why pretreated lignocellulose requires 100 times as much enzyme for complete saccharification than does pretreated starch. Additionally, recalcitrance is used when describing the kinetic phenomena in which the rate of cellulase digestion slows during extended reaction; i.e., a portion of the substrate is more digestible early in the reaction than that at the end of reaction. Recalcitrance is also used to describe the phenomenon by which pretreatment yields both digestible and indigestible fractions with essentially identical compositions.

Plant biomass has evolved superb mechanisms for resisting assault on its structural sugars from the microbial and animal kingdoms. These mechanisms are comprised of both chemical and structural elements. Natural factors believed to contribute to the slow reaction of lignocellulosic feedstock with chemicals or enzymes include: (1) the waxy barrier and dense cells forming the rind of grasses and bark of trees, (2) the vascular structures that carefully limit liquid penetration throughout plant stems, (3) the composite nature of the plant cell wall that restricts aqueous penetration from cell to cell, (4) the hemicellulose coating on the cellulose-containing microfibrils of the cell wall, (5) the crystalline nature of cellulose itself, and (6) the inherent difficulty enzymes have acting on insoluble surfaces like cellulose. Furthermore, we now suspect that the structural elements of many lignocellulosic materials react to the processes of pretreatment in ways that also reduce enzymatic digestibility. For example, we believe that: (1) high mechanical pressure, such as that from plug feeders, collapses the natural vascular structure, (2) dilute acid chemical pretreatments may permit cellulose to re-anneal, leading to "hornification" of cellulose in microfibers, and (3) some pretreatments may permit lignin to become soluble and "plate out" on cellulose surfaces during the cool-down phase. These "process-induced" causes of recalcitrance must be understood and overcome.

\section{Surface Characterization}

Lignocellulosic biomass is a composite structure with crystalline cellulose, hydrated hemicellulose, and lignin as major components. To date, the best enzyme cocktails proposed for the saccharification of this material are synergistic mixtures of essentially defined enzyme activities, primarily those that degrade cellulose. The heterogeneous nature of the substrate and the complexity of the enzyme cocktails suggest that traditional studies of bulk properties will not provide the detailed understanding required for knowledge-based advancements in this field.

\section{The Biomass Surface Characterization Laboratory}

The new Biomass Surface Characterization Laboratory (BSCL) was constructed to provide the most modern commercial surface characterization equipment for studying relevant biomass surfaces. It houses top-of-the-line electron, optical, and scanning probe microscopes. To assure optimal performance, NREL 
provided a special 2,500 sq. ft. facility to house these sensitive instruments, where acoustic, thermal, mechanical, and radio frequency interference is controlled to ensure optimal performance.

The BSCL offers a unique integrated core facility for solving biomass recalcitrance related problems. As planned and built, this laboratory offers the following specific overall benefits to DOE OBP: (1) these tools are located at the site of biorefinery process stream generation at NREL, (2) these tools cover appropriate ranges in imaging power for biomass, (3) these tools have the specific configuration needed to excel in biomass imaging, and (4) the entire facility is under one facility with consolidated management for consistent quality and scheduling control. In this plan, we will describe the key barrier of biomass recalcitrance and the way these instruments and the facility will be put to use to address this barrier.

\section{Addressing OBP Barriers}

Many of the barriers to producing low cost mixed sugars from lignocellulose reflect elements of the recalcitrance of the substrate. Knowledge based approaches to reducing these barriers include research in: (1) pretreatment, (2) enzymes, and (3) process integration. Success in improving pretreatment, enzymes, and process integration will also address the feedstock cost barrier by improving the yield of sugar per ton of feedstock and may improve the economics of the sugar biorefinery by generating streams that provide opportunities for higher value products. Thus, defining and characterizing barriers related to biomass recalcitrance is key to enabling lignocellulose biorefineries.

\section{Integration into the AOP}

In the FY05 AOP, the Sugar Area was restructured to better highlight future technical accomplishments and improve organization and alignment with OBP interests. The Sugar Area is now organized into three tasks: Pretreatment and Enzymatic Hydrolysis (PEH), which addresses the unit operations of the conversion platform, Sugar Processing Integration (SPI), which addresses the integration of unit operations into a process, and Targeted Conversion Research (TCR), which develops new knowledge in specific technical areas required to advance unit operations and processes. Figure 1 shows the specific questions the BSCL activities will address (in bold) in each task and how the areas apply to the overall goal of cost reduction for the biorefinery process.

An examination of Figure 1 shows that key technical goals in the TCR task are posed as questions, the solutions to which provide the PEH task with direct data, which will be used to improve specific process steps, or elements of process steps. The SPI task then uses these new findings from PEH to guide improved and more useful plant integration tests. Because TCR operates at a higher level of inquiry and seeks answers to questions that are critical, but not always well understood, TCR covers more topics, but with fewer resources per topic than PEH or SPI. Thus, the chart shows fewer topics per task and reduced BSCL usage as we move from left to right.

The Gantt chart attached as Appendix C provides a detailed example of how the BSCL tools might be used to resolve the biomass recalcitrance barrier. Note that in this detailed plan C and D milestones are proposed over a 3-year period and are designed to bring us closer to the program's objectives. BSCL tools are necessary to execute most, but not all of these milestones. We propose to conduct work in all three research areas the first year; however, from the Feedstock Integrant topic we will get a mature understanding of the issues early on, and then transfer that knowledge to Pretreatment early in Year 2. At that time Feedstock work is diminished or off-ramped. Pretreatment and enzyme research activities function largely in parallel using the same, optimal feedstock until 2008. These two Integrant topics 
trade-off samples and findings periodically during this time, with continuous improvement the overall goal of this close coordination. This integrated approach is new to the OBP Program.

\section{Access for Stakeholders}

The BSCL will be available for external users. Three mechanisms are available to biomass stakeholders interested in using the facilities. Cooperative Research and Development Agreements (CRADAs) allow biomass stakeholders to incorporate NREL resources in proposals or to financially support researchers at NREL to work on directed projects. Work For Others (WFO) contracts are designed for biomass stakeholders to pay for specific and defined work at NREL on the behalf of the stakeholder. Analytical Service Agreements (ASA) are contractual instruments with pre-approved terms limited to three months or less and $\$ 50,000$ or less of work. In the case of these agreements, the cost to the biomass stakeholder is the fully loaded labor and operating cost.

\section{BSCL Technology Transfer}

It is critical for the success of the National Bioenergy Center's (NBC) BSCL that imaging opportunities and quality data are transmitted to the appropriate stakeholders in a timely fashion. To achieve this, we must first communicate the availability of these tools to those potentially interested; and second, we must manage access to the facility so that DOE OBP stakeholders are the principal beneficiaries. We will employ several diverse methods to achieve this goal.

(1) Website: Non-proprietary experimental data collected at the NBC BSCL will be stored on a publicly accessible website. This website will contain not only BSCL imaging data from key experiments, but also a link to experimental detail. The website will also host a quarterly report regarding BSCL activities and accomplishments. (2) Workshop: We will host semi-annual biomass imaging workshops at NREL to engage other workers in the field and stimulate interest in partnerships with industry. These workshops should follow the Biofuels Colloquy format, which began each session with key questions to be answered by the participants, open discussion, and then construction of a white paper summarizing these question and challenges. (3) Publication Plan: Developing a plan to publish and present key findings using the BSCL tools in the best venues. (4) Client Plan: Work to educate and then establish new partnerships with technology developers using the one-on-one approach. For example, several companies wishing to learn more about the BSCL and ways of collaborating approached us within a month of the BSCL dedication. The details of this BSCL client building plan will be expanded during the course of 2005 , where we will become more familiar with tool use costing and other business constraints. (5) Presentation Plan: We will present on the equipment, plan, and progress at the OBP Peer Review (every other year) to get reviewers input or direction and benefit of work.

\section{Summary}

In applying the BSCL tools to biomass recalcitrance, the most powerful ally we have is the basic knowledge of the molecular structure of plant cell wall polysaccharides and the ability to trace chemical changes at the micron and nanometer scale. This new asset represents a new "systematic tool box" specifically targeting acquisition of new understanding needed for biomass conversion fundamentals. 
Figure 1: Sugar Area Tasks' Contribution to Ethanol Cost Reduction (BSCL-related contributions in bold)

\begin{tabular}{|c|c|c|c|}
\hline & $\begin{array}{l}\text { Targeted Conversion } \\
\text { Research }\end{array}$ & $\begin{array}{l}\text { Pretreatment \& } \\
\text { Enzymatic Hydrolysis }\end{array}$ & $\begin{array}{l}\text { Sugar Processing } \\
\text { Integration }\end{array}$ \\
\hline & Ask/Answer... & Apply... & Demonstrate... \\
\hline $\begin{array}{l}\text { Improved } \\
\text { Fermentation }\end{array}$ & $\begin{array}{l}\text { - What are the sugar } \\
\text { degradation reactions? } \\
\text { - What are the toxic } \\
\text { compounds and where do } \\
\text { they originate? }\end{array}$ & $\begin{array}{l}\text { - Control sugar degradation } \\
\text { reactions } \\
\text { - Minimize hydrolyzate } \\
\text { toxicity }\end{array}$ & \multirow{3}{*}{$\begin{array}{l}\text { - Generation of process } \\
\text { relevant residues for } \\
\text { characterization } \\
\text { - Recycle water impact } \\
\text { - Control of sugar degradatior } \\
\text { reactions } \\
\text { - Reduction of toxic } \\
\text { compound production } \\
\text { - High solids pretreatment, } \\
\text { hydrolysis, \& fermentation } \\
\text { - Alternative pretreatments } \\
\text { - Real time monitoring of } \\
\text { - feedstock \& intermediates } \\
\text { - Improved post-pretreatment } \\
\text { - Hrocessing } \\
\text { - Real solids mixing } \\
\text { - } \text { sugar concentrations } \\
\text { chderstand feedstock } \\
\text { characteristic's impact on } \\
\text { process performance }\end{array}$} \\
\hline $\begin{array}{l}\text { Improved } \\
\text { Pretreatment }\end{array}$ & $\begin{array}{l}\text { - Where are cellulose, } \\
\text { residual hemicellulose, \& } \\
\text { lignin location in cell walls? } \\
\text { - Why and how do biomass } \\
\text { fractions pretreat } \\
\text { differently? } \\
\text { - How does cell wall } \\
\text { ultrastructure change with } \\
\text { pretreatment? } \\
\text { - How does ultrastructure of } \\
\text { microfibrils change with } \\
\text { pretreatment? } \\
\text { - How do physiochemical } \\
\text { properties of biomass } \\
\text { change with pretreatment? }\end{array}$ & $\begin{array}{l}\text { - Effect of gross structure on } \\
\text { recalcitrance } \\
\text { - Gross structure after } \\
\text { chemical pretreatment } \\
\text { - Impact of lignin } \\
\text { rearrangement on } \\
\text { hydrolysis due to } \\
\text { pretreatment } \\
\text { - Mass transfer effects }\end{array}$ & \\
\hline \multirow[t]{2}{*}{$\begin{array}{l}\text { Improved } \\
\text { Enzymatic } \\
\text { Hydrolysis }\end{array}$} & $\begin{array}{l}\text { - How do cellulases bind to } \\
\text { cellulose - mechanism \& } \\
\text { substrate? } \\
\text { - What is the rate of } \\
\text { cellulase procession? } \\
\text { - Can the CBH I mechanism } \\
\text { be improved? } \\
\text { - How does lignin inhibit } \\
\text { cellulase performance? }\end{array}$ & $\begin{array}{l}\text { - Feedstock-pretreatment- } \\
\text { enzyme matrix } \\
\text { - Rheology effects on mixing } \\
\text { and pumping } \\
\text { - Role of hemicellulose and } \\
\text { lignin in inhibiting } \\
\text { cellulase performance } \\
\text { - Effect of non-cellulase } \\
\text { enzymes on biomass } \\
\text { structure } \\
\text { - Enable less severe } \\
\text { pretreatments with enzymes }\end{array}$ & \\
\hline & Basic Knowledge & Unit Operations & Integration Issues \\
\hline
\end{tabular}

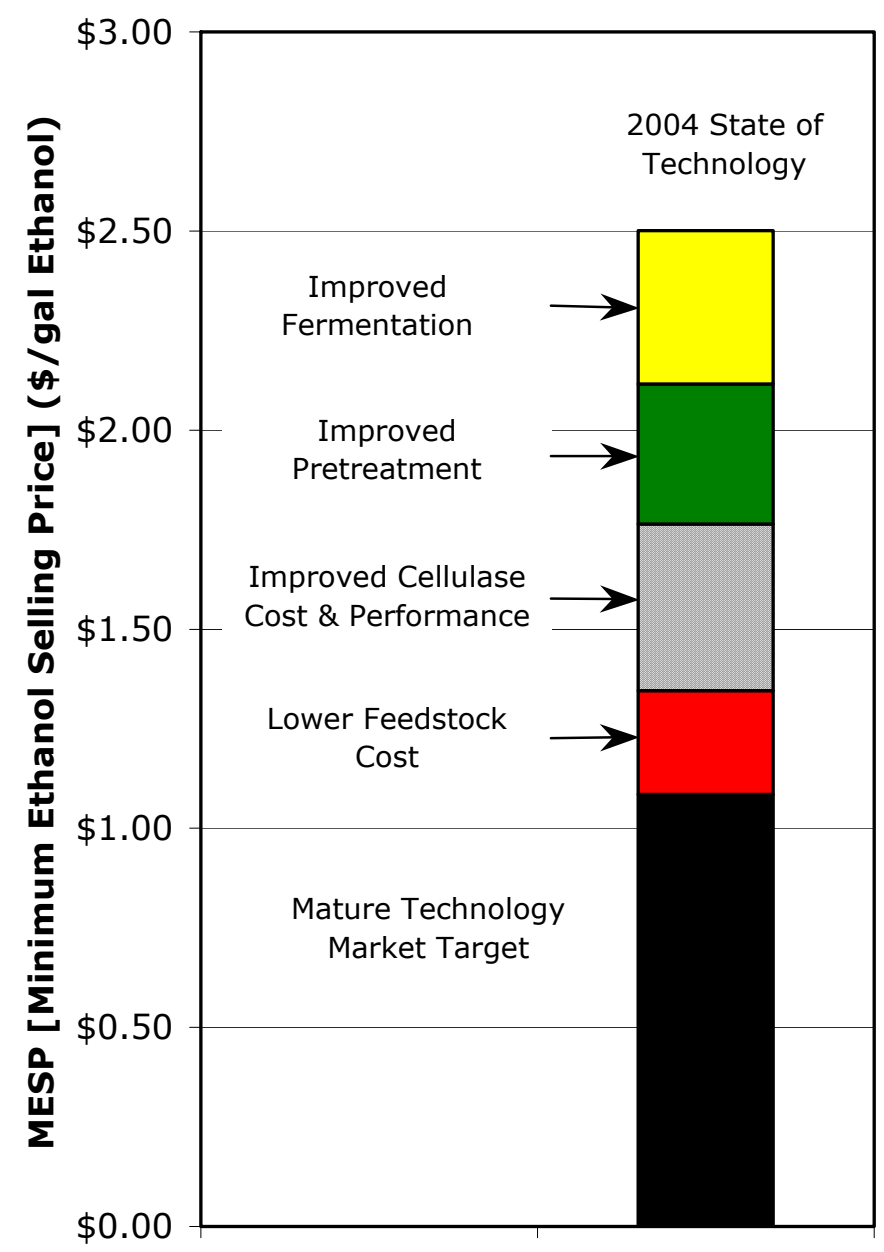




\section{Appendix A: Tools of Surface Characterization}

The Biomass Surface Characterization Laboratory is equipped with modern surface probe, electron, and optical microscopes for surface characterization.

Scanning Electron Microscopy - FEI Quanta FEG 400 ESEM.

The SEM is one of the most versatile and widely used tools of modern science as it allows the study of the surface morphology of both biological and non-biological materials. By scanning an electron probe across a specimen, high-resolution images of the topography of a specimen over a wide range of magnifications (as high as 200,000x) and with great depth of field can be obtained. Characterization of fine particulate matter in terms of size, shape, and distribution as well as statistical analyses of these parameters, may be performed. Biological samples like biomass for scanning electron microscopy analysis are usually coated with a thin layer of electron dense material, such as carbon or atomized gold. New developments in designing scanning electron microscopy sample chambers and optics permit the analysis of samples containing some natural moisture. This configuration is called the environmental mode. This capability is critical for analyzing biomass fractions where the ability to image the specimen with some moisture content and no surface coating is, at times, highly desirable.

\section{Atomic Force Microscopy (AFM) - DI-Veeco MultiMode PicoForce System.}

Atomic Force Microscopy is a recently developed very powerful scanning probe microscope surface analyses tool. Atomic Force Microscopy images not only the topography of the sample surface at very high magnification, it also measures the attractive and repulsive forces between the scanning probe tip and the sample surface, thus providing both height and phase images. It is increasingly applied to biological samples because of its unprecedented atomic level resolution and ability to function in ambient environments that do not require extensive sample preparation; an important consideration for concerns about conserving native structure. Scanning probe techniques allow the study of dry or hydrated surfaces directly using a tapping-probe. High-resolution Atomic Force Microscopy images of the plant cell wall surface have recently been reported, both at NREL and elsewhere. New applications have been added to scanning probe microscopy, for example, chemical force probe microscopy and pico-force measurements, which provide tremendous opportunities to trace the interaction dynamics of biocatalysts and substrate. We will use Atomic Force Microscopy routinely to analyze the results of pretreatment and enzyme action on biomass surfaces.

\section{Transmission Electron Microscopy - FEI Tecnai F20.}

This is the leading imaging technique for high-resolution general biological research. Transmission Electron Microscopy allows the user to determine the internal structure of materials, either of biological or non-biological origin. Materials for Transmission Electron Microscopy must be specially prepared to thicknesses that allow electrons to transmit through the sample, much like light is transmitted through materials in conventional optical microscopy. Because the wavelength of electrons is much smaller than that of light, the optimal resolution attainable for Transmission Electron Microscopy images is many orders of magnitude better than that from a light microscope. Thus, Transmission Electron Microscopy can reveal the finest details of internal structure - in some cases as small as individual atoms.

Magnifications of 350,000x can be routinely obtained for many materials. For biological samples, cell structure and morphology are routinely determined, whereas the localization of antigens or other specific components within cells requires specialized preparative techniques, such as shadowing or staining with high contrast compounds. Compositional analysis of a material may also be obtained by monitoring secondary X-rays produced by the electron-specimen interaction using energy dispersive X-ray microanalysis. Thus detailed maps of elemental distribution can be produced from multi-phase materials or complex, bio-active materials. Images obtained from Transmission Electron Microscopy are twodimensional sections of the material under study, but for structural biology, cryo- or cold-stage electron 
microscopy can give resolution of multi-subunit proteins and clusters and tomography provides reconstruction of complex images in a three dimensional profile.

Near-field Scanning Optical Microscopy - DI- Veeco Aurora-3 NSOM.

Near-field Scanning Optical Microscopy is a very recent development in surface analysis science and this tool is considered to be a methodology "in progress" for biomass applications. Near-field Scanning Optical Microscopy is a scanning probe tool, where the probe is a solid "light pipe" serving to provide both a topographic surface scan (similar to the Atomic Force Microscopy) and a source of light energy for spectrophotometry. Near-field Scanning Optical Microscopy permits surfaces to be viewed with a long depth of field light microscope, which has been modified and optimized to conduct secondary spectrophotometric analysis such as UV/VIS, fluorescence, and laser Raman. Furthermore, complex biological surfaces can be mapped using these integrated spectroscopic systems; provided background fluorescence and resolution challenges can be addressed. Improved Near-field Scanning Optical Microscopy systems will be applied to the analysis of chemically pretreated and enzyme digested biomass samples. Single-molecule detection of labeled proteins is another common application related to Nearfield Scanning Optical Microscopy. The BSCL uses an Olympus IX71 inverted microscope fitted with a DP70 high resolution CCD camera to perform single molecule microscopy.

\section{Confocal Microscopy (CFM) - Nikon E800; C1 Microscope.}

Confocal microscopy offers several advantages over conventional optical microscopy, including controllable depth of field, the elimination of image degrading out-of-focus information, and the ability to collect serial optical sections from thick specimens. The key to the confocal approach is the use of spatial filtering to eliminate out-of-focus light or flare in specimens that are thicker than the plane of focus.

Confocal microscopy can produce optical sections, in sequence through relatively thick sections or wholemount specimens. Based on the optical section as the basic image unit, data can be collected from fixed and stained specimens in single, double, triple, or multiple-wavelength illumination modes, and the images collected with the various illuminations and labeling strategies will be in register with each other. This stack of image planes can be digitally assembled into three dimensional images in which every point is in excellent focus. 


\section{Appendix B: Specific Strategies to Use BSCL Tools to Overcome Biomass Recalcitrance Barriers}

We propose integrating three key research topics to gain understanding of biomass recalcitrance and find solutions for reducing the cost of biomass deconstruction to fermentable sugars. These topics are referred to as "Integrants" in the Gantt chart in Appendix C.

\section{Biomass Recalcitrance Integrant A: The Feedstock}

The initial feedstock we will investigate will be corn stover, which is an assembly of unequal portions of internode, node, leaf, sheath, and some tassel. (This list is in the approximate order of preponderance by weight.) Corn stover produced from grain corn in the United States is field dried and allowed to reach full senescence - a process by which the available nutrients in plant tissue are first depleted and then cells in the stems dehydrate. The structure of corn stems and grasses is distinguished from that of woods by the distribution of bundles of vascular cells, i.e., in monocots such as corn they are spaced throughout the cross section (see above) and in dicots (trees) they are grouped close to the rapidly growing outer tissues, such as the bark and cambium. These bundles

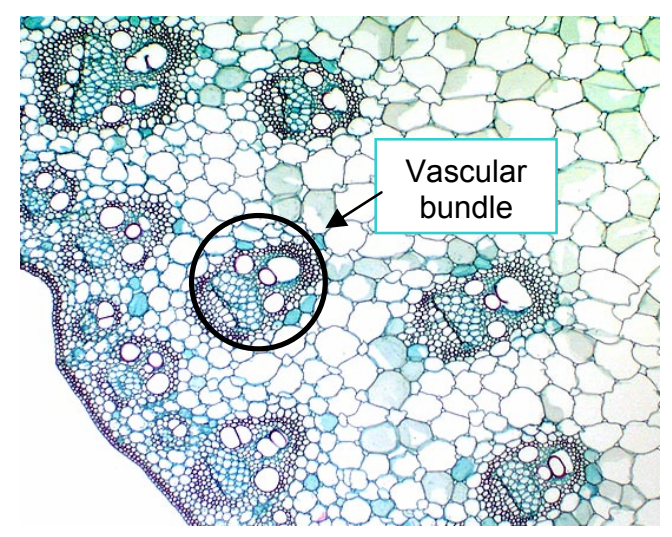
are composed of large xylem cells (which transport water) and phloem cells (which transport dissolved solids, such as salts and nutrients). Cells in the vascular bundles are similar to cells near the rind of the stem, which are thick walled cells. These cells contain thick secondary cell walls rich in cellulose. The remainder of the stem is filled with thin walled cells called parenchyma cells. Most of the mass of the corn stem is associated with the vascular bundles (ca. 70\%). Most of the lignin in the corn stem is also contained in these thick walled cells.

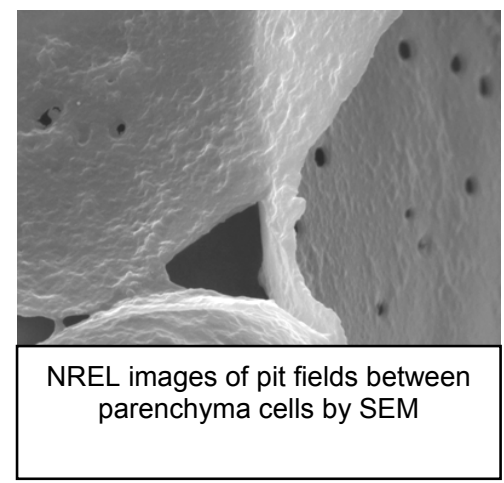

Chemicals and larger enzymes entering corn stems must find pathways for penetration. Depending on the anticipated size of corn stem fragments subjected to the process and the state of the rind, we now recognize that the natural vascular structures in stems regulate diffusion of solutes to the sites of hydrolysis. It is indeed possible that changes in in-field practices; biomass storage, biomass milling, soaking, and chemical treatment can improve chemical penetration. We must understand this process at the ultrastructural level in order to improve it.

Plan: We will design specific research aimed at answering the following key questions within 3 years.

Objective 1. What are the chemistries of the ultrastructural surfaces of the corn plant vascular and parenchyma cells? Where is the cellulose? Where is the lignin?

Objective 2. What pore sizes are needed for effective penetration of native and pretreated biomass by key endoglucanases, exoglucanases, and hemicellulases? 
Objective 3. What is the natural pore and pit size distribution in corn stems? Address cracks versus pore diffusion impregnation. Can different post harvest or size reduction methods affect this?

\section{Biomass Recalcitrance Integrant B: The Pretreatment}

Chemical treatments of biomass are known to be necessary to permit the more effective use of cellulase and other biomass degrading enzymes. Pretreatments are either conducted under acidic or alkaline conditions and usually at elevated temperatures (from $100^{\circ} \mathrm{C}$ to $210^{\circ} \mathrm{C}$, depending on the specific method). The best current theory about pretreatment is that it alters the structure of the plant cell wall in a way that increases accessibility of cellulases to cellulose. Understanding the pretreatment mechanism and then learning how to control and optimize it is the overall objective.

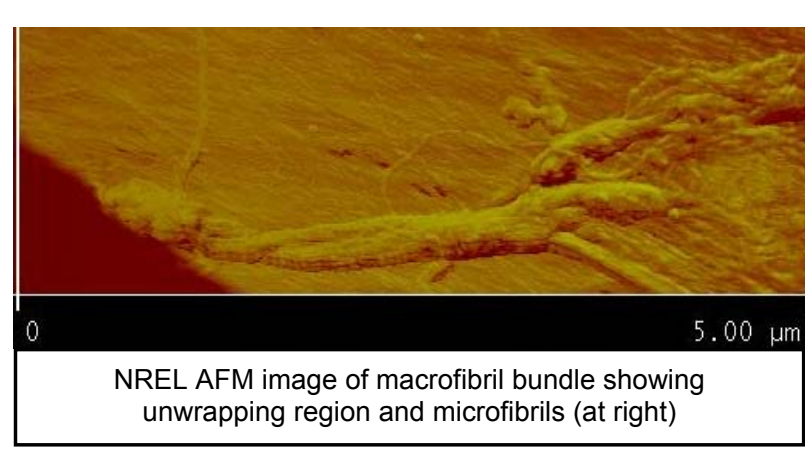

\section{Pretreatment does NOT} alter the

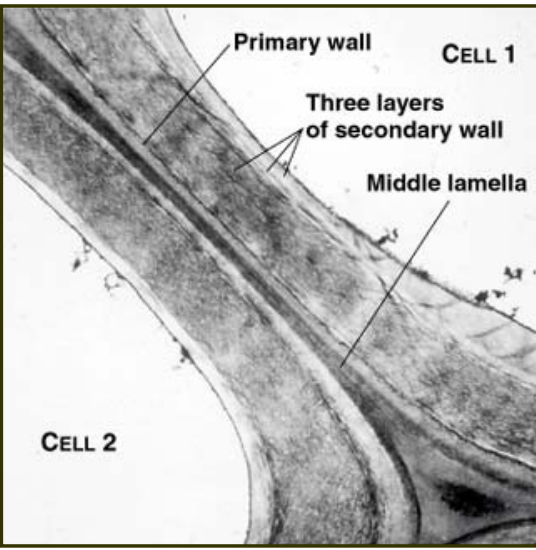
degree of crystallinity of cellulose (cellulases are known to be more effective on amorphous, i.e., non crystalline, cellulose). The plant cell wall is comprised of finely woven mats of primary microfibrils. Microfibrils are thought to be 20 - to 40-nm diameter structures of cellulose surrounded by hemicellulose and lignin. In order to improve the effectiveness of pretreatments and later enzyme action we must learn more about the ultrastructural details of these microfibrils using the capabilities of the BSCL. Knowledge gained from "Biomass Recalcitrance: Part A" work will serve as the baseline control to trace chemical and structural changes during pretreatment. This work differs from work in the past in that our new approach will be to use fully integrated experiments to solve the recalcitrance challenge (i.e., one sample taken from native structure, to pretreatment, to final enzyme hydrolysis).

Plan: We will plan specific research aimed at answering the following key questions within 3 years.

Objective 1. How do general pretreatment chemicals alter corn stem tissue at the level of the cells and cell walls? How does the natural pore size distribution in corn stems impact acid penetration? How does the new pore size distribution following pretreatment impact enzyme penetration in biomass?

Objective 2. How do pretreatment enzymes (non-cellulases), such as xylanases and pectinases, alter corn stem tissue at the level of the cells and cell walls and assist pretreatment efficacy?

Objective 3. How do the CAFI 2 and other pretreatments affect the structure of plant cell walls at microfibril level?

\section{Biomass Recalcitrance Integrant C: The Enzymes}

Cellulase enzymes degrade cellulose in the microfibrils of plant cell walls. The microfibrils are the only location of cellulose in plants, and most cellulose can be found in the thick walled cells of the vascular bundles. Cell walls are composed of cellulose-containing microfibril networks embedded in non- 
cellulosic matrices. The microfibril is about $10 \mathrm{~nm}$ in diameter and thought to comprise a hemicellulose sheath wrapped around a solid cellulose core. The hemicellulose likely keeps the cellulose stands from forming strong and regular interactions between themselves, which could result in poorly digestible aggregates of cellulose. Inside the microfibril, plant cellulose is probably a monoclinic crystal with two dominant longitudinal faces, the 1,0,0 face and the 1,1,0 face. Recent evidence (see STEM image) is that most cellulases bind only to the lesser face, the $1,0,0$ face.

The question is, have $T$. reesei enzymes evolved to function optimally on the plant cell wall cellulose? From cellulase

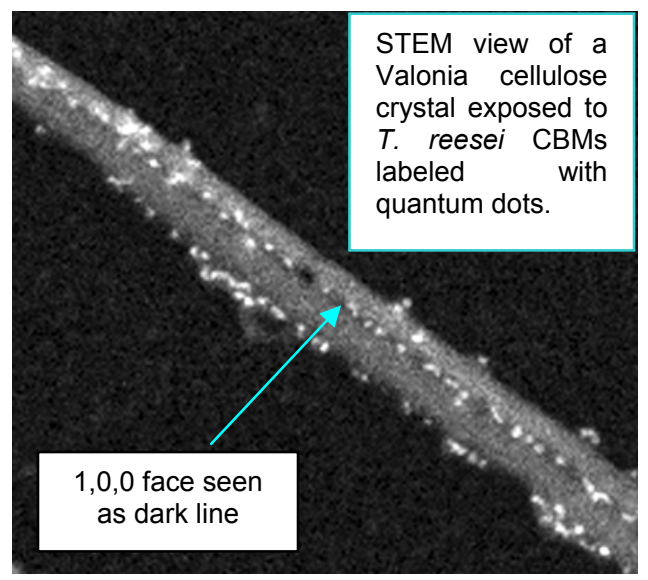
kinetics alone, we would never be able to answer this question. Enzyme kinetics have always been a measure of the "ensemble average" result from experiment, and thus sugar release values from biomass can never deliver information about the actual site of individual enzyme action. Because of this dilemma, we do not know if cellulose recalcitrance is due to enzyme inadequacy, enzyme-substrate mismatch, or both. We must be able to improve cellulases using an informational approach, considering that 20 years of "mixing and testing" individual cellulase proteins has yielded only modest progress towards an improved cellulase system. A major challenge in this experimental plan is the development of a new method to prepare and study actual cell wall microfibrils. We will study microfibrils in situ; that is, as they lie on the cell wall surface. However, we will also attempt to isolate microfibrils from corn stem cell walls in a chemically and physically relevant form. This has never been accomplished. We will use partial chemical digestion and chaeotropic salts to dislodge macrofibrils and a new "Laser Capture Micro Dissection" system to harvest specific plant cell fractions. Once isolated, or even just uncovered, these structures will be tagged and studied by SEM, AFM, and NSOM.

A further novel aspect proposed here is the intention to produce a "severity series" of cell wall microfibrils. Chemical treatments that span conditions designed to just uncover the cellulose core in microfibrils, to high severity conditions that leave only the cellulose core crystallite will be planned. We are especially concerned that even moderate severity pretreatments often result in a highly aggregated fibrillar matrix, which is even more highly inaccessible by cellulases. We must prove or disprove this hypothesis in order to improve pretreatment and enzyme use.

The function of this key (most important) cellulase enzyme type, the "processive" cellulase (i.e., the T. reesei CBH I) is not known. This enzyme must be improved in its actual performance, that is, performance on plant cell walls in a number of hydrolysis events per unit time. The Biotech Company subcontracts in effect from 2000 to 2004 did not accomplish this goal. It is a difficult problem, yet we consider it achievable with proper preparation. To accomplish this objective, a functioning model of the function of CBH I must be developed. We are about two years into a 5-year effort to use mutational analysis and large-scale computer modeling to understand $\mathrm{CBH}$ I at the kinetic AND energetic level. That is to say, how does it work? A first step toward this goal is the measurement of the linear rate of translation of $\mathrm{CBH}$, how fast does it move on crystalline cellulose? Do different CBMs affect this rate and can this strategy be used to improve CBH enzymes? This work can be accomplished

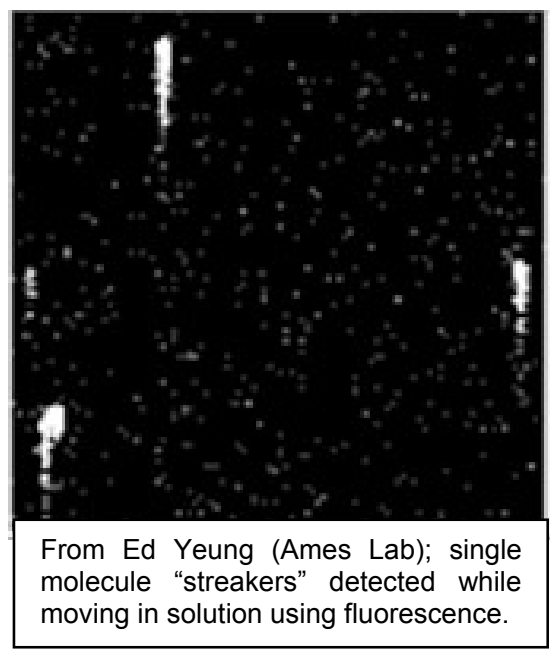
by single molecule microscopy (SMM). 
Cellulase has long been thought to be especially susceptible to loss of the native cell walls of plants, and lignin is the probable adsorbent. We now know that re-precipitated lignin (resulting from pretreatment protocols) may also be the primary site of enzyme loss, but this has not been proven. Research questions that will be investigated to test this theory will include: Can we prove this occurs using our BSCL tools? Can we map the probable sites of lignin loss in native and pretreated corn stems? Can we then adapt new pretreatments and/or enzymes to reduce these undesirable effects?

To improve cellulase performance, we must learn more about the actual target substrate for these enzymes - at the level of the cell wall. This knowledge will enable us to improve cellulase cocktails and pretreatment approaches in tandem and in an integrated manner with very significant possible benefits in biomass conversion and in the economics of biomass conversion.

Plan: We will plan specific research aimed at answering the following key questions within 3 years.

Objective 1. What face of the cellulose crystal is really the preferred substrate for fungal and bacterial enzymes? What structures may permit better enzyme procession and can we prepare them? How can pretreatment expose or generate a better cellulose surface? Note the tie to Pretreatment research.

Objective 2. How do cellulases bind to and move along the cellulose surface? What is the physical rate of procession? Can we measure this property and relate it to classical kinetics? Can we engineer enzymes to improve this natural property?

Objective 3. What role does lignin really play in inhibiting enzymes acting on plant cell walls? This information can be used to engineer better enzymes (with lower lignin binding properties) and improved pretreatment protocols. Can we see enzymes bound to lignin deposits? 


\section{Appendix C: BSCL Use Plan}

Task Nane

-Notice that this plan is not structured by current subtasks, but by unknowns regarding Biomass Recalcitrance

-This work would result in final reports usable for drafting new solicitation(s)

-This is more than a BSCL Use plan, it is a Biomass Recalcitrance roadmap 2005-2008

-To meet most MS, the work will require full integration of skills (this does not ft well into old silos)

\section{Integrant 1: Hatural Structure of Grasses and Woods Impacting Conversion}

Obj 1. Acquire and test tools to study the uttrastructure of corn stover \& hard woods reproducibly

DMS. Install A.MM, NSOM, EsEM and TEM in a new facility in the FI

DMS. Assess and acquire additional key tools as budgets permit

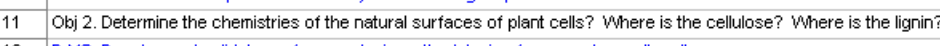

12 D MS: Develop and validate surface analysis methodologies for corn stem cell wall

13 D MS: Map the location of polysaccharides in corn stern cell walls

14 D MS: Map distribution of native lignin at the cell and cell wall leved

15 D MS: Develop and validate surface analysis methodologies for wood cell wal

16 D MS: Map the location of polysaccharides in wood cell walls

17 Obj 3. Determine the natural pore size distribution in corn sterns and show why this is important.

18 D MS: Denonstration of ultra-structural characterization of pores in biomass using animation

19 D MS: Determine if post harvest practices can affect pore sizes or cracks or surface chenistry

20 CMS: Reconmend post harvest or size reduction factors or methods for optimal conversion

Integrant 2: Structure of Pretreated Biomass and Impacts on Cellulase Action
Obj1 How do DA pretreatments atter and improve digestibility of corn stover cell walls?

D MS: Characterize macroscopic properties of dilute acid pretreated biomass most greatly impacting susceptibility of cellulose to enzymatic

D MS: Determine how the natural pore size distribution in corn stems impacts acid penetration?

D MS: Determine how the new pore size distribution following pretreatment inpacts enzyme penetration?

D MS: Map lignin deposition on cell surfaces following DA pretreattment

D MS: Map lignin removal or modification following DA, pretreatment

C MS: Map distribution of lignin or re-precipitated lignin across the structural features residual in material from one pretreatment

CMS: Recommend optimal DA, pretreattment conditions for corn stover relative to enzyme digestibitty and lignin effect

Obj 2. How do pretreatment enzymes (non-cellulases) atter corn stem tissue at the cell wall level?

D MS: Cell wall component susceptibility to pretreatment chenistries and enzyymatic degradation (Joirt MS)

D MS: How does the natural pore size distribution in corn stems impact enzyme penetration?

CMS: Recommend optimal non cellulase treatment for enhanced cellulase digestibility

Obj 3. How do the CAFI 2 and other pretreatments affect the structure of cell walls at microfibril level?

D MS: Deliver inaging study of CAFI 2 samples

Integrant 3: Understand and Improve Enzyme Performance on Best Substrates

39 Obj 1. Determine what face of the cellulose crystal is really the preferred substrate for enzymes?

40 D MS: Develop methods to isolate cell wall components (esp microfilbrils)

1 D MS: Determine what faces of cellulose in corn cell microfibrils may permit better enzyme action.

2 D MS: Determine if DA pretreatment severity can atter or improve exposure to this face

3 CMS: Report development of optinized corn cell cellulose surfaces or propose new strategies (ie, for solicitation)

Obj 2. Determine how cellulases bind to and move along the cellulose surface?

D MS: Verify the model of CBHI Action on cellulose using CHARMM

D MS: Deternine the physical rate of $\mathrm{CBH} I$ procession experimentally?

D MS: Relate linear rate of procession and classical kinetic values to support energetics aspects of $\mathrm{CBH}$ I model

3 D MS: Accuire and analyze biologically relevant computer model of $\mathrm{CBH}$ I on cellulose

D MS: Test and report modifications to enzymes that could inprove processivity

C MS: Report improved CBHI or propose new strategies for its improvement (ie, for solicitation

Obj 3 . Determine what role lignin really plays in inhibiting enzymes acting on DA biomass.

D MS: Attempt to inage enzymes bound to lignin or lignin deposits and analyze effect?

4 CMS: Report development of lignin binding reduced cellulases or propose new strategies (ie, for solicitation)

55

BSCL and Biomass Recalcitrance Workshop

57 BSCL Imaging Workshop 2005

58 D MS: Report from Workshop with comments and contacts

ESCL Imaging Workshop 2006

D MS: Report from Workshop with comments and contacts

1 BSCL Imaging Workshop 2005

D MS: Report from Workshop with comments and contacts

63

4 Impact on OBP B Milestone

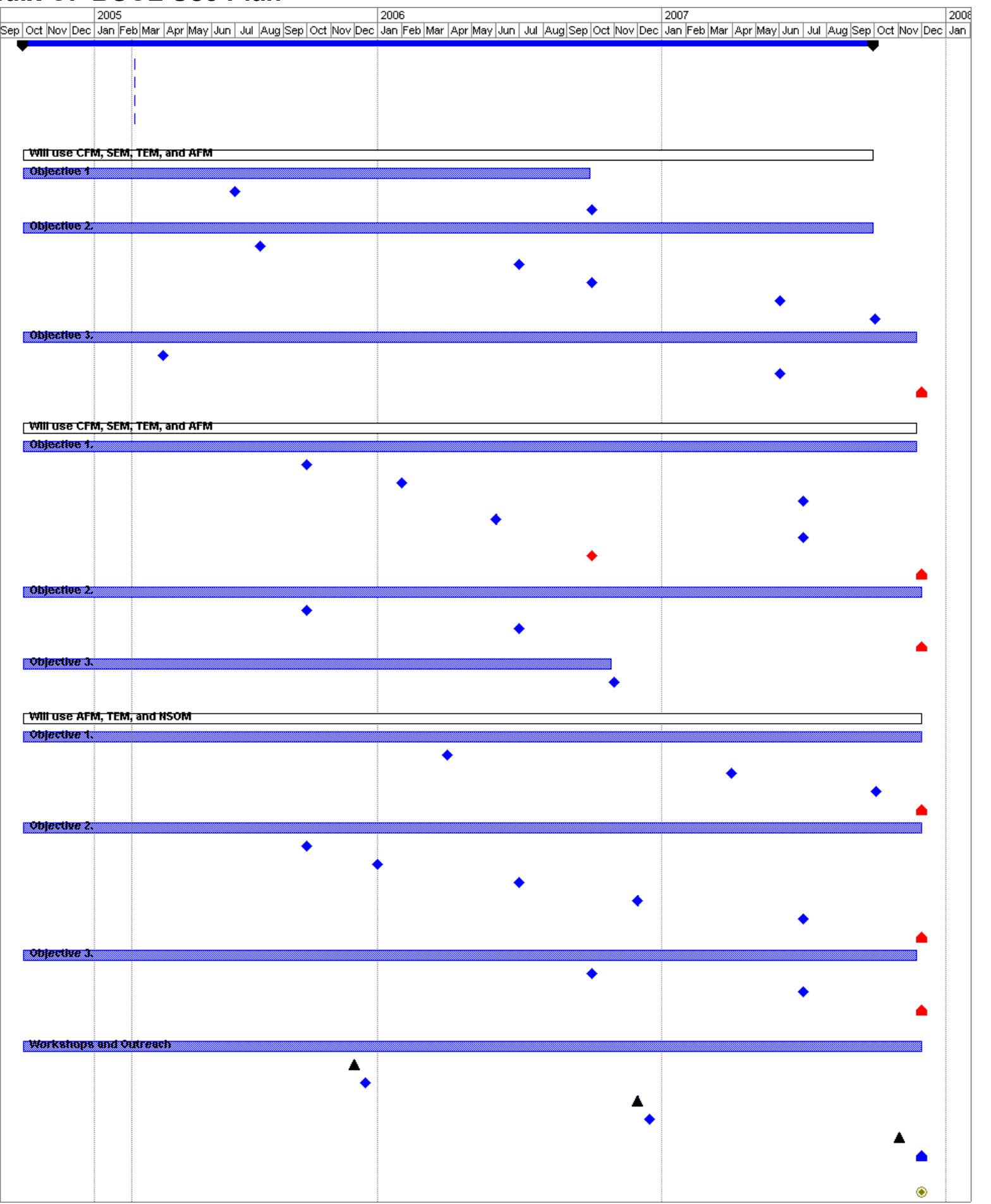




\section{REPORT DOCUMENTATION PAGE}

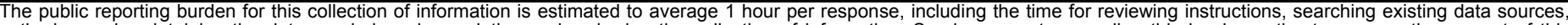

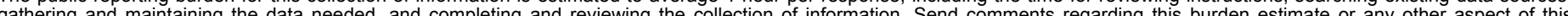

chould be aware that notwithstanding any other provision of law, no person shall be subject to any pene

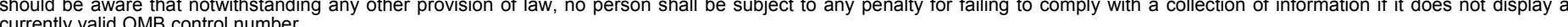

PLEASE DO NOT RETURN YOUR FORM TO THE ABOVE ORGANIZATION.

\begin{tabular}{l|l|l|l} 
1. REPORT DATE (DD-MM-YYYY) & 2. REPORT TYPE & 3. DATES COVERED (FrOm - TO)
\end{tabular}

August 2005

Technical Report

4. TITLE AND SUBTITLE

BSCL Use Plan: Solving Biomass Recalcitrance

5a. CONTRACT NUMBER

DE-AC36-99-G010337

5b. GRANT NUMBER

5c. PROGRAM ELEMENT NUMBER

6. AUTHOR(S)

M. Himmel, T. Vinzant, S. Bower, and J. Jechura

5d. PROJECT NUMBER

NREL/TP-510-37902

5e. TASK NUMBER

BB052340

5f. WORK UNIT NUMBER

7. PERFORMING ORGANIZATION NAME(S) AND ADDRESS(ES)

National Renewable Energy Laboratory

1617 Cole Blvd.

8. PERFORMING ORGANIZATION REPORT NUMBER

Golden, CO 80401-3393

NREL/TP-510-37902

9. SPONSORING/MONITORING AGENCY NAME(S) AND ADDRESS(ES)

10. SPONSOR/MONITOR'S ACRONYM(S) NREL

11. SPONSORING/MONITORING AGENCY REPORT NUMBER

12. DISTRIBUTION AVAILABILITY STATEMENT

National Technical Information Service

U.S. Department of Commerce

5285 Port Royal Road

Springfield, VA 22161

13. SUPPLEMENTARY NOTES

14. ABSTRACT (Maximum 200 Words)

Technical report describing NREL's new Biomass Surface Characterization Laboratory (BSCL). The BSCL was constructed to provide the most modern commercial surface characterization equipment for studying biomass surfaces.

15. SUBJECT TERMS

BSCL; recalcitrance; lignocellulosic

\begin{tabular}{l}
\hline \multicolumn{3}{|l|}{ 16. SECURITY CLASSIFICATION OF: } \\
\hline \begin{tabular}{l|l|l|} 
a. REPORT & b. ABSTRACT & c. THIS PAGE \\
Unclassified & Unclassified & Unclassified \\
& & \\
\hline
\end{tabular} \\
\hline
\end{tabular}

\begin{tabular}{l|l} 
17. LIMITATION & 18. $\begin{array}{l}\text { NUMBER } \\
\text { OF ABSTRACT } \\
\text { OF PAGES }\end{array}$ \\
UL & \\
& \\
\hline
\end{tabular}

19a. NAME OF RESPONSIBLE PERSON

19b. TELEPHONE NUMBER (Include area code) 